STUDII

\title{
STUDIUL DREPTULUI ÎN ȘCOLILE ROMEI
}

\author{
ANTICE
}

DOI: 10.24193 /SUBBiur.65(2020).4.24

Data publicării online:

16.03 .2021

\section{Cristina POP*}

Rezumat: Întrucât singurele reguli de natură juridică ce erau cunoscute în regalitatea romană constau în arhaicul fas, educația romană din monarhie a fost una care se potrivea unor oameni tradiționali, inspirând tinerilor respectul pentru obiceiurile strămoșilor. Mai mult, deoarece civilizația romană nu s-a dezvoltat autonom, ea a asimilat structurile și tehnicile elenistice, mult mai evoluate. Prin urmare, sistemul de învățământ juridic roman s-a bazat pe gândirea greacă și, sub anumite aspecte, a fost creat din dorința cetățenilor de a avea o educație în drept. Dacă la începutul Republicii observăm un sistem informal de educație juridică, odată cu începutul Imperiului, acest domeniu s-a schimbat treptat, găsind o formă finală în Dominat.

Cuvinte cheie: drept roman, jurisconsult, jurisprudentia, educație juridică, școli de drept.

* Asist. dr. Cristina Pop, Facultatea de Drept, Universitatea Babeș-Bolyai din Cluj, cristina.pop@law.ubbcluj.ro. 


\title{
LEGAL EDUCATION IN ANCIENT ROME'S SCHOOLS
}

\begin{abstract}
As the only legal rules known in the Roman Kingdom were the archaic fas, Roman education from monarchy was an education suitable for traditional people, instilling in youth the respect for the customs of the ancestors. Moreover, because Roman civilization did not develop autonomously, it assimilated the structures and techniques of the much more evolved Hellenistic one. Therefore, Roman legal education system was based on the Greek thinking and, under certain aspects, it was created from the desire of citizens to have a Law education. If at the beginning of the Republic we observe an informal legal education system, with the beginning of the Empire, this field changed gradually, finding a final form in the Dominate.
\end{abstract}

Keywords: Roman Law, jurisconsult, jurisprudentia, legal education, law schools.

Roma Antică, binecunoscută lumii întregi ca model de civilizație creatoare a mari personalități politice, militare, literare, istorice, dar nu numai, a fost cea care a furnizat și științei dreptului prestigioși gânditori și practicieni. Astfel, în paginile care urmează ne propunem să analizăm etapele pe care societatea romană le-a parcurs în cadrul arealului educaţional juridic, cu scopul de a demonstra că, atât în perioadele în care nu existau școli specializate în domeniu, cât și în cele în care aceste instituții au luat amploare, perseverența romană a scos în prim-plan caractere care și-au pus definitiv amprenta asupra întregului sistem de drept. Totodată, considerăm că odată cu centralizarea învățământului juridic și cu înființarea acestui tip de instituții în întregul Imperiu Roman, model perpetuat de-a lungul istoriei până în prezent, s-au pus bazele unei reale revoluții în drept fără de care evoluția acestei materii ar fi fost mult mai anevoioasă.

Începându-ne excursul cu o caracterizare de ansamblu a educației romane antice, punctăm faptul că modalitatea de învățământ oferită tinerilor 
în monarhie a fost una potrivită unui popor cu adânci trăsături rurale, tradiționale, ce insufla respect pentru obiceiurile strămoșilor (mos maiorum). Cum de-a lungul timpului civilizația romană nu s-a dezvoltat autonom, ea a asimilat, începând cu sec. II î.Hr., structurile și tehnicile civilizației elene, mult mai evoluată cultural. Astfel, a doua jumătate a Republicii va cunoaște un sistem elementar şi practic de învăţare a Dreptului, prin care ucenicul lua contact direct cu munca maestrului său. Ulterior, avându-l ca exemplu pe Cicero, instrucțiunile primite de către studenți s-au transformat într-o expunere teoretică sistematizată din partea profesorului. Dreptul Roman a fost astfel promovat la rangul unei discipline științifice, însă adevăratele școli în domeniul juridic s-au înființat progresiv-în Principat-și au preluat un caracter oficial odată cu urcarea pe tron a lui Dioclețian. În același timp, educația juridică și-a dobândit instrumentele definitive prin alcătuirea unor tratate elementare, cum ar fi Instituțiile lui Gaius, manuale de procedură, comentarii și culegeri sistematice de jurisprudență, totul culminând cu reforma din învățământ a împăratului Iustinian.

Ius civile, ca vector juridic roman, a avut o existență continuă și o dezvoltare concomitentă cu cea a societății pentru mai mult de un mileniu. Datorită longevității și perenității lui, ne permitem să încadrăm Dreptul Roman printre sistemele juridice antice care pot prezenta într-o lumină limpede modalitatea de instruire a celor care s-au angajat în studierea unui domeniu atât de vast. Furnizând lumii acest dar neprețuit al unei gândiri juridice mature și îndrumându-ne spre decantarea caracteristicilor adevăratei naturii a dreptului ${ }^{1}$, materia pe care o studiem reprezintă un exemplu de urmat pentru multe sisteme juridice contemporane. În alt plan, experiența didactică ne-a pus față în față cu necunoașterea de către studenți a faptului că

\footnotetext{
${ }^{1}$ Augustus Henry Frazer Lefroy, Rome and To-day, în Harvard Law Review nr. 20, 1907, p. 606.
} 
personalităţile marcante republicane nu aveau în spate studii în acest domeniu, neexistând în acea epocă nici măcar ideea de a înființa școli de Drept. Cumulând motivele enunțate mai sus, considerăm că deținem suficiente resorturi pentru a dezvolta, în cele ce urmează, titlul articolului de față.

Chiar dacă pentru o lungă perioadă de la înființarea Cetății Eterne romanii nu au conceput necesitatea studierii chestiunilor de natură legală, în timp, educația juridică a ocupat la Roma o poziție distinctă în dezvoltarea societății. Vom observa cum, de la rigorismul și caracterul secret al regulilor juridice existente în Regalitate și de la inexistența școlilor de Drept în Republică, se va ajunge chiar la implicarea autorităților în înființarea instituțiilor de acest tip, în Imperiu. Faptul se motivează prin aceea că, științific vorbind, Dreptul Roman s-a elaborat şi extins semnificativ, comparativ cu oricare alt sistem juridic contemporan lui. În același timp, este datoria noastră să amintim că romanii au reușit să se dezvolte într-un cadru benefic și fără existența unui ansamblu instituționalizat de educație juridică, exemplu fiind întreagul parcurs de la Romulus până la Iulius Caesar².

După cum am dezvoltat într-un articol anterior³, în perioadele de început ale Romei, dreptul și religia erau considerate ca inextricabile, iar aceleaşi persoane administrau și aplicau atât chestiunile de natură juridică, cât și pe cele religioase. Putem astfel afirma, în sens larg, că știința Dreptului Roman își are originile în activitatea colegiului preoților (pontifices/ sacerdotes publici), deoarece acesta avea ca rol acordarea de sfaturi juridice, dar și soluționarea conflictelor dintre cetățeni, în timpul Romei regale și la

\footnotetext{
2 Andrew Riggsby, Roman Legal Education, în A Companion to Ancient Education, Editor W. Martin Bloomer, John Wiley \& Sons, Inc., 2015, p. 444.

3 Cristina Pop, Unele aspecte ale desprinderii juridicului de sub tutela sacrului în dreptul roman, în Studia Iurisprudentia, nr. 2/ 2014. p. 117-128.
} 
începutul Republicii ${ }^{4}$. Pontifii făceau parte din cea mai înaltă clasă socială și politică a comunității, prin naștere obținând statutul de patricieni; în același timp, spre deosebire de majoritatea populației romane, ei dețineau un statut economic privilegiat. Pe scurt, erau persoane bogate, patrioți de spiță aristocratică, capabili să își asume datorii sociale și politice importante. Credincioși tradițiilor pontificale, sacerdoții erau considerați gardieni ai legilor, reprezentând cei dintâi „avocați” ai dreptului sacramental.

Lecturându-l pe Titius Livius înțelegem care a fost cauza din spatele inexistenței ideii de a înființa școli în care să se predea Dreptul: preoții Regalității ascundeau de oamenii din popor regulile aplicabile domeniului juridic, acestea fiind cunoscute doar în cercul lor restrâns ${ }^{5}$. Mai mult, formulele sacre de judecată erau transmise doar anumitor persoane, pe care sacerdoții le considerau demne de a le urma în funcție ${ }^{6}$. Ca o concluzie, poporul roman depindea, în monarhie, de activitatea sacerdoților pentru implementarea oricărui chestiuni legale sau pentru rezolvarea plângerilor de natură juridică7.

Înaintând în timp, considerăm că debutul cunoașterii la scară largă a Dreptului la Roma își are bazele în apariția Legii celor XII Table (449 î. Hr.). Totuşi, în ciuda implementării primului cod de legi scrise, pentru a-și proteja privilegiile, preoții au continuat, o perioadă, să se considere unici protectori

\footnotetext{
${ }^{4}$ Alte atribuții deținute de către acești pontifi au fost: medierea relaţiilor dintre cetățeni şi zei, efectuarea ceremonialurilor religioase, pregătirea celor care se dedicau vieții sacerdotale, supravegherea formalităților de înmormântare, a regulilor aplicabile în timp de război și a regulilor aplicabile în temple.

5 Titus Livius, $A b$ Urbe condita, 4.3.9.

6 Bernard Mineo, A companion to Livy, John Wiley\&Sons, New Jersey, 2015, p. 361 apud Ahmet Karakocali, Changes in Roman Legal Education, în The Online Journal of New Horizons in Education, vol. 6, 2016, p. 43.
}

7 Ahmet Karakocali, op.cit., p. 42-43. 
ai Dreptului ${ }^{8}$. Astfel, în momentul în care ius s-a desprins de fas nu au încetat să activeze și în domeniul dreptului secular9 ${ }^{9}$ și adeseori, prin deciziile pe care le-au luat, preoții au jucat un rol important, atât pe timp de pace cât și pe timp de război. Deoarece dezvoltarea societăţii devenise incompatibilă cu sistemul juridic încorsetat, iar plebeii obțineau tot mai multe privilegii de natură politică, socială și economică, acest tip de jurisprudență pontificală, o știință secretă în regalitate și la începutul erei republicane, a devenit publică la sfârşitul secolului IV î.Hr. ( 304 î. Hr.). Gnaeus Flavius, fiul unui libert, devenit secretarul lui Appius Claudius Caecus este cel care, alături de alte detalii de natură juridică, le-a făcut cunoscute și pe cele referitoare la procedura de judecată existentă în acel timp (legis actiones) ${ }^{10} . \mathrm{Cu}$ toate acestea, tradiția semnalează faptul că Appius Claudius ar fi fost mintea din spatele întregii acțiuni, însă s-a folosit de ucenicul său în acest sens ${ }^{11}$. Ca o consecință, cunoștințele despre ceremoniile religioase și formalitățile necesare derulării unui proces au ajuns accesibile tuturor, putându-se pune, în următoarele secole, bazele unui sistem centralizat de instruire în sfera legală.

Cronologic, o altă figură importantă pentru tema lucrării de față este Tiberius Coruncanius (consul în anul 280 î.Hr.) şi primul pontif plebeu (primus profiteri coepit) ${ }^{12}$, considerat a fi cel dintâi „profesor” de Drept ${ }^{13}$. Atribuirea acestei titulaturi se datorează faptului că s-a arătat dispus să răspundă, public, tuturor întrebărilor adresate de către cetățenii doritori să

\footnotetext{
8 Clyde Pharr, Roman Legal Education, în The Classical Journal, Vol. 34, Nr. 5, 1939, p. 258.

9 Anton Hermann Chroust, Legal Profession in Ancient Republican Rome, în Notre Dame Law Review, vol. 30, 1954, p. 100-101.

${ }^{10}$ Clyde Pharr, op.cit, p. 259.

${ }^{11}$ Ibidem.

12 Cicero, Pro Plancio, 8.

13 Pomponius, D. 1.2.2.35, 38 .
} 
cunoască Dreptul ${ }^{14}$. Aceeași informație o avem și de la Pomponious, care ne relatează faptul că primul cetățean roman care a profesat în domeniul juridic a fost Coruncanius ${ }^{15}$, alături de P. Aelius Paetus Catus și P. Acilius ${ }^{16}$. O altă sursă care să întărească cele cunoscute despre Coruncanius este Cicero: marele orator ne expune despre acelaşi personaj că ar fi fost primul care a oferit consultații juridice publice ${ }^{17}$. Faptul că acești jurisconsulți nu se îndeletniceau cu predatul, în adevăratul sens al cuvântului, ne demonstrează tot Cicero, scriind despre Q. Scaevola că obișnuia să permită numai anumitor persoane să asiste la consultaţiile oferite clienţilor săi ${ }^{18}$. Sub aspect istoric, putem numi acest moment leagănul jurisprudenței romane ca știință, autoritatea și contribuția lui Cornicanus fiind inestimabilă în domeniu.

Ulterior, influența literaturii grecești şi, în particular, metodele ştiințifice utilizate de școlile de filozofie au conturat ideea de a da dreptului scris o formă organizată, „artistică”19. Astfel, Cato cel Bătrân (234-149 î.Hr.) a fost cel dintâi care a inițiat aranjarea unui număr de patru legi într-o ordine sistematică, însă finalizarea acestei munci a aparținut lui Quintus Mucius Scaevola (140-82 î.Hr.) care, în anul 100 î. Hr., a împărțit și clasificat dreptul pozitiv după subiectele pe care le tratau reglementările legale existente în acea perioadă ${ }^{20}$. Așadar, pentru prima dată în istoria Dreptului Roman, această știința îmbrăca o formă. Munca de pionerat a celor doi a uşurat considerabil

\footnotetext{
14 Charles Phineas Sherman, Study of Law in Roman Law Schools, în Yale Law Journal, Faculty Scholarship Series, 1908, p. 500.

15 Pentru o biografie completă a acestei personalități:

https://www.perseus.tufts.edu/hopper/text?doc=Perseus:text:1999.04.0104:entry=ticoruncanius-bio-1, accesat la data de 20.08.2020.

${ }^{16}$ Pomponius, D. 1.2.2.38.

17 Andrew Riggsby, op.cit., p. 445.

18 Cicero, Brutus, 80.306.

19 Charles Phineas Sherman, op.cit.

${ }^{20}$ Ibidem.
} 
modalitatea de abordare a acestui domeniu de către practicienii ei ${ }^{21}$. Dacă în timpul ultimelor două secole ale Republicii emiterea unei opinii juridice era o caracteristică a instituției patronatului, tot în acest context istoric se conturează un mic și foarte bine definit cerc al elitei romane, ce reprezenta autoritatea în domeniu: jurisconsulții răspundeau întrebărilor adresate de către prieteni, clienți și inclusiv de către cetățeni din public. Astfel, romanii au cunoscut, pentru întâia oară în existența lor, o categorie de persoane care se ocupa cu studierea îndelungată și cu analiza problemelor juridice, motiv ce a dus la transformarea Dreptului într-o știință precisă, detaliată și tehnică²2.

Printre cei care au contribuit la crearea științei Dreptului încă din timpul Republicii romane este şi Publius Rutiliu Rufus (158-78 î. Hr.). Cunoscut ca un mare avocat, a fost totodată și un adevărat autodidact în acest domeniu. Știm despre el că era foarte căutat de către clienți, iar dorința lui de a învăța, integritatea profesională și etica înaltă au cucerit admirația cetățenilor. Cicero îl descrie ca un model de inocență nepătată, iar Velleius Paterculus menționează că Rufus a fost o persoană extraordinară, nu doar dintre cei de vârsta sa, ci dintre toți oamenii pe care îi cunoștea ${ }^{23}$.

De mare ajutor pentru perioada Republicii și pentru a demonstra faptul că nici în acele timpuri nu existau școli de Drept este însăși personalitatea bine-cunoscutului Cicero (106-43 î. Hr.). Profesia lui nu era aceea a unui jurist, în sensul înțeles astăzi, ci a unui adevărat orator republican. $\mathrm{Cu}$ toate acestea, a arătat un interes puternic față de știința

\footnotetext{
21 Îndatoririle lor erau acelea de a răspunde întrebărilor cu caracter juridic (respondere), de a reprezenta clienții în instanță (agere) și de a redacta acte de procedură (cavere). Pentru detalii a se vedea Pop Cristina, Câteva considerații privind accesul la justiție în Dreptul Roman, Revista de Ştiințe Juridice nr.1/ 2019, p. 261-274.

22 John Anthony Crook, Law and Life of Rome, Cornell University Press, Ithaca, New York, 1967, p. 88 apud Ahmet Karakocali, op.cit., p. 43.

23 Anton Hermann Chroust, op.cit., p. 141.
} 
Dreptului, privind-o ca pe o componentă obligatorie a cunoștințelor deținute de orice bărbat din elita romană (carmen necessarium). Cicero mărturisește ${ }^{24}$ că a învățat pe de rost conținutul Legii celor XII Table, ca pe un exercițiu patriotic, iar nu ca o obligație juridică, practică devenită desuetă câțiva ani mai târziu. Tot în lucrările lui descoperim menționat un anume Mucius, pontifex, care deși nu preda, modalitatea lui de a emite consultații juridice a trezit interesul unor personaje din elita societății spre a deprinde cunoștințe în acest domeniu ${ }^{25}$.

Completând lista personalităţilor romane care s-au îndeletnicit cu scrierea și sistematizarea normelor juridice, îl amintim în anul 39 î. Hr. pe jurisconsultul Alfenus Varus care a publicat un studiu în domeniul juridic ce putea fi ușor utilizat de către cei interesați de descifrarea și înțelegerea acestui domeniu ${ }^{26}$. Până în acest punct al dezvoltării societății romane, observăm că în nicio sursă istorică nu se amintește de existența școlilor de Drept, în comparație cu cele de retorică.

După cum vom observa, spre deosebire de Imperiu, în perioada republicană nu se impunea deținerea unei diplome pentru a putea profesa în domeniul juridic; prin urmare, nu trebuiau urmate cursurile niciunei școli de drept sau entități organizate în acest sens. Elita respectivelor timpuri considera faptul că orice formă de predare sistematică și, în același timp, remunerată se situa sub demnitatea membrilor ei. În Republică, modalitatea de învățare a rămas aceeaşi ca cea din perioada pontifilor, fără a mai avea, însă, un caracter secret: observare, imitare și, apoi, asocierea cunoștințelor dobândite. În același timp, jurisconsulții republicani nu acordau foarte multă

\footnotetext{
24 Cicero, De Legibus, 2.23 .

25 Cicero, Brutus, 306. Andrew Riggsby, op.cit., p. 445.

${ }^{26}$ John Hazel, Who's who in the Roman World, Routledge, London, 2001, p. 9 apud Ahmet Karakocali, op.cit., p. 44.
} 
atenție problemelor de interpretare a definițiilor, de clasificare a noțiunilor și nici analizei sau întrebărilor din dreptul comparat sau istoriei juridice. Caracterizţi prin pragmatism și din dorința lor de a vedea realitatea concretă, jurisconsulții au fost interesați numai de existența și aplicarea dreptului contemporan $l^{2}{ }^{27}$. În ceea ce îi privește pe oratores $^{28}$, unii dintre ei au mers atât de departe încât au respins orice studiu juridic, susținând că sunt suficiente, pentru a pleda, stilul oratoric și dicția, studiate în școlile epocii ${ }^{29}$. Acești oratori acuzau faptul că Dreptul este o știință care nu inspiră, este nefolositoare şi care nu ar duce decât la ruinarea talentelor retorice ale cuiva $^{30}$.

Ultimul secol al Romei republicane intervine cu modificări asupra metodei de predare, respectiv de dobândire a cunoștințelor juridice. Așadar, cine dorea să deprindă virtuozitatea în Drept și își permitea acest lucru din punct de vedere financiar, se alătura unui jurisconsult faimos pentru a studia această știință (instituere ${ }^{31}$ ), iar odată primit sub protecția profesorului, studentul locuia cu familia lui. În acest cadru învățăcelul lua parte la consultațiile pe care maestrul le dădea clienților și, de câteva ori pe săptămână, îl însoțea pe acesta la Forum, observându-i modul în care își realiza profesia (de cele mai multe ori, aceasta presupunea activarea doar în faza in iure a procesului ${ }^{2}$ ). În acest mod, învățăcelul lua contact direct cu practica juridică, deprindea spiritul Dreptului Roman, modalitățile în care acesta putea fi aplicat și învăța arta de a soluționa cazuri concrete. Datorită

\footnotetext{
27 Anton Hermann Chroust, op.cit., p. 128.

28 Pentru o descrie mai detaliată a acestei profesii a se vedea Pop Cristina, op.cit.

${ }^{29}$ Anton Hermann Chroust, op.cit., p. 122.

30 Anton Hermann Chroust, Legal Profession in Ancient Imperial Rome, în Notre Dame Law Review, vol. 30, 1955, p. 571.

${ }^{31}$ Pomponius, D.1.2.2.47.

$3^{2}$ Anton Hermann Chroust, op.cit., p. 598.
} 
contextului în care se desfășura, considerăm modalitatea de studiu ca fiind una esențialmente aristocrată33, iar printre jurisconsulții care procedau astfel Pomponius îi amintește pe Aquilius Gallus și Balbus Lucilius34. Din nefericire, această metodă de predare a fost amenințată, apoi abolită de noile idei pedagogice importate din Grecia. Gândirea elenă, conform căreia o persoană trebuie să studieze în cadrul unui program uniformizat, și-a făcut repede intrarea la Roma și, bineînțeles, a afectat în sens negativ clasa oratorilor. Alături de A. H. Chroust considerăm că punctul de turnură în istoria educației juridice la Roma l-a reprezentat momentul oferirii cetățeniei romane, de către Iulius Caesar, tuturor profesorilor greci de gramatică și de retorică, prin aceasta ei primind recunoaștere oficială 35 . În acest sens, marele Horațiu remarcă faptul că cei care fuseseră odată captivi, grecii, și-au cucerit propriii stăpâni prin introducerea artei în rustica Latium ${ }^{36}$.

Ca o consecință directă a inexistenței școlilor în care să se predea Dreptul, în această perioadă a Romei Antice nu sunt cunoscute nici cărți cu conținut juridic, privite strict ca manuale. Urmele de informații deținute referitoare la literatura republicană romană ne sugerează existența anumitor lucrări care aveau un caracter mai mult general și introductiv. Îndeletnicirea de a preda Dreptul rămânea, în Republică, una a persoanelor cu un statut social inferior, cu toate că domeniul juridic devenise printre puținele areale care puteau fi accesibile tuturor cetățenilor liberi37. Chiar dacă finalul Republicii a furnizat o știință a Dreptului ce putea fi pusă în practică,

33 Anton Hermann Chroust, Legal Profession in Ancient Republican Rome, în Notre Dame Law Review, vol. 30, 1954, p. 113-114.

34 Pomponius, D.1.2.2.42.

35 Anton Hermann Chroust, Legal Profession in Ancient Imperial Rome, în Notre Dame Law Review, vol. 30, 1955, p. 599.

${ }^{36}$ Horațiu, Satire şi Scrisori, 2.1.156.

37 Andrew Riggsby, op.cit., p. 446. 
reamintim că aceasta nu era o materie învăţată într-o anumită instituţie, fiindcă predarea Dreptului nu devenise atractivă pentru oratorii și avocații romani. După cum am mai spus, această profesie se învăța prin observare și asociere, mai ales datorită faptului că răspunsurile jurisconsulților erau date, de cele mai multe ori, în public ${ }^{3}$.

În Principat, s-a făcut simțită încercarea de a specializa și de a dobândi autonomia domeniului juridic față de politică, retorică și față de alte domenii. În acelaşi timp, printre juriști au apărut și cei din clase sociale mai puțin favorabile, chiar dacă majoritatea încă făcea parte din elita societăţii. În această perioadă, înființarea școlilor în domeniu a fost influențată și de interesul principelui de a deține controlul în acest areal. Astfel, începând cu domnia lui Augustus anumiți jurisconsulți au primit dreptul de a oferi răspunsuri juridice în public și, prin urmare, s-a stabilit recunoașterea oficială a științei dreptului ca distinctă și prețuită. În timp, opunându-se tiraniei militare și întregii birocrații care luase naștere odată cu înființarea Principatului, dar mai ales centralizării și monopolizării domeniului legal de către puterea imperială, jurisconsulții au refuzat să mai ofere acele responsa. Ca o consecință, și-au îndreptat atenția spre scrierea și predarea Dreptului ${ }^{39}$ : o parte dintre jurisconsulți nu se limitau numai la emite răspunsuri juridice, însă se și prezentau pe ei înșiși ca profesori de Drept, iar aşa cum ne specifică Aulus Gellius ${ }^{40}$, în birourile lor s-au iscat controverse în ceea ce privește învățarea procedurii civile în public. Considerăm validarea oficială a

38 Anton Hermann Chroust, Legal Profession in Ancient Republican Rome, în Notre Dame Law Review, vol. 30, 1954, p. 108.

39 Anton Hermann Chroust, Legal Profession in Ancient Imperial Rome, în Notre Dame Law Review, vol. 30, 1955, p. 541.

40 Aulus Gellius, Nopți Atice, 13.13.1. 
precticienilor în Drept ca fiind un prim mare apor adus de conducerea Principatului în dezvoltarea științei, ca atare.

O a doua mare contribuție pe care a avut o implicarea autorităţilor centrale în chestiunile juridice o reprezintă angajarea jurisconsulților în funcții publice. Un dezavantaj al acestei duble învestiri a fost acela că timpul dedicat „carierei universitare” se limita: dacă despre Labeo se spune că ar fi predat numai câte şase luni în fiecare an, tocmai pentru a avea suficient răgaz pentru a așterne în scris cugetările sale cu privire la problematicile de natură juridică pe care le ridica profesia aleasă, perioada scurtă pe care o ofereau predatului jurisconsulți ca Salvius Julianus, Papinian, Ulpian, Paul, Modestin se motivează prin faptul că aceștia erau reținuți foarte mult de obligațiile funcțiilor publice pe care le ocupau ${ }^{41}$.

Mai mult, odată cu Vespasian (69-79) experții juridici angajaţi ai Statului erau remunerați, iar cei mai importanți dintre ei au primit chiar funcția de consul ${ }^{42}$. Tot în timpul domniei acestui împărat s-a impus cerința ca personalul administrației publice să fie format din cetățeni cu studii în domeniul în care funcționau, practica fiind implementată definitiv de către împăratul Hadrian (117-138). Pozițiile cheie în administraţia imperială, în birouri, în cancelarii și în provincii erau frecvent deținute de către avocați care studiaseră Dreptul. În același timp, pentru a ocupa acest statut, respectivul cetățean trebuia să demonstreze că anterior fusese un jurist cu un bagaj profesional bogat; altfel spus, el trebuia să arate că era un om care cunoștea regulile juridice și, prin calificarea sa, își permitea să profeseze în cele mai înalte posturi ale Statului ${ }^{43}$. Necesitatea obținerii unei diplome pentru a

\footnotetext{
${ }^{41}$ Anton Hermann Chroust, op.cit., p. 603.

42 Andrew Riggsby, op.cit., p. 446.

43 Anton Hermann Chroust, op.cit., p. 529-530.
} 
accede în funcțiile de guvernământ, a avut consecințe dezastruoase pentru vechii oratori care, nedeținând acest titlu, nu mai puteau profesa44. Însă, poate chiar mai mult decât retorica, Dreptul a oferit tinerilor romani cariere profitabile.

Cum mai sus am amintit despre munca de pionerat a lui Cato şi al lui Scaevola din ultimul secol al Republicii, adăugăm că, în paralel cu dezvoltarea modalității de sistematizare a legilor, și-au făcut apariția la Roma primele școli private de Drept. Astfel, orice jurisconsult (magister juris) care își permitea să reunească un număr de studenți, nu era oprit de lege din a le preda acestora cunoștințele deținute. Deoarece această practică nu a fost restricționată aproximativ 300 de ani, perioada despre care vorbim o putem considera ca epoca de aur a jurisprudenței clasice romane ${ }^{45}$.

Din perspectivă istorică, încă de la începutul Imperiului s-au pus bazele a două școli de Drept, rivale prin opiniile pe care le abordau, care au dominat societatea romană până în epoca lui Marcus Aurelius (169-177)46: şcoala Sabiniană și cea Proculiană. Anumiți autori consideră că originea înfiinţării acestor școli a stat chiar în acordarea, de către Augustus, a privilegiului ius publice respondendi47. Adiacent, amintim că influența lui Cassius, discipolul lui Sabinus, îl determină pe Plinius cel Tânăr48 să facă referire la existența unei forme organizate de învățământ juridic, aducând aminte de școala Sabiniană sub denumirea de Cassiană. Gaius însuși

\footnotetext{
44 Idem, p. 572-573.

45 Charles Phineas Sherman, op.cit., p. 501.

46 Edwin Charles Clark, Roman Private Law, Biblo \& Tannen Booksellers \& Publishers, Incorporated, Madison, 1965, p.128.

47 Pomponius, D. 1.2.2.49. În perioada lui Tiberius, această regulă nu şi-a mai găsit aplicabilitate, odată cu acordarea aceluiași privilegiu către Masurius Sabinus, avocat ce făcea parte dintr-o pătură socială inferioară.

48 Plinius cel Tânăr, Scrisori, 7.24.8.
} 
amintește că este adeptul acestei școli. El nu folosește niciuna dintre aceste denumiri, însă menționează cele două mari personalități care i-au trecut pragul, Sabinus şi Cassius. Găsind în Gaius titulatura de praeceptores pentru cei doi jurisconsulți, nu ne putem îndoi de faptul că în perioada de început a Imperiului a existat un sistem educațional juridic instituționalizat ${ }^{49}$. Despre viața lui Masurius Sabinus nu se cunosc detalii, cu excepția faptului că împăratul Tiberius l-a recunoscut ca jurisconsult, devenind primul cetățean ce nu fusese senator și obținuse această distincție ${ }^{50}$. Sabinus, care potrivit lui Pomponius l-a sprijinit pe acesta în emiterea de opinii juridice ${ }^{51}$, a fost primul care a înființat o adevărată școală de Drept, secta Sabinianorum ${ }^{2}$. În acest sens, el a adoptat metoda de predare sistematizată, obicei care era foarte răspândit în școlile de filozofie din Grecia53. Așadar, aceste școli au fost organizate sub forma unor societăți, în cadrul cărora studenții erau membrii, iar profesorul era conducătorul sau președintele (magister, antecessor, professor). Pentru derularea studiilor, elevii achitau celui din urmă o anumită taxă, Sabinus fiind unul dintre cei care obişnuiau să uziteze de această practică, motivată pe starea financiară precară a maestrului ${ }^{54}$. Pe de altă parte, Ulpian însuși punctează faptul că este sub demnitatea unui jurist să ceară compensație pentru munca sa ca profesor, chiar dacă i se pare onorabilă o remunerație oferită ca donație de către un student. Acesta considera știința dreptului ca fiind o materie sacră, ce nu putea fi comparată cu un bun pus la

\footnotetext{
49 Andrew Riggsby, op.cit., p. 447-448.

50 Clyde Pharr, op.cit., p. 261.

${ }^{51}$ Pomponius, D. 1.2.2.50.

$5^{2}$ Ahmet Karakocali, op.cit., p. 44.

53 Charles Phineas Sherman, op.cit., p. 502.

54 Pomponius, D. 1.2.2.50.
} 
vânzare pentru un anume preț55. Ca o dovadă în plus a faptului că Masurius Sabinus a fost într-adevăr un profesor de Drept reiese și din faptul că a redactat pentru studenții săi un manual numit Libri Tres Iuris Civilis, care a rămas un elemnt de bază din curricula acelei școli, până domnia lui Hadrian sau poate chiar mai târziu ${ }^{56}$.

Cele două instituții private au fost mai mult decât școli în care se preda gândire juridică, opinii sau doctrină. Ele erau organizații educaționale în care știința se transmitea și se studia într-o manieră sistematizată, de către un personal calificat. Acest lucru reiese din faptul că școlile erau numite scholae, iar profesorii sau membrii purtau denumirea de praeceptores ${ }^{57}$, aşa cum am precizat mai sus. Ca model organizatoric au fost școlile grecești de filozofie cum sunt Academia Platoniană, Școala Epicuriana și Peripatusul Aristotelian. Un alt motiv pentru care considerăm că cele două instituții îmbinau predarea cunoștințelor cu pedagogia ar fi acela că le întâlnim și sub titulatura de stationes ius publice docentium aut respondetium ${ }^{5}$. Cu toate acestea, se pare că locul unde se desfășurau cursurile nu era unul stabil, cel puțin în primul secol al erei noastre. Așadar, oricare dintre profesori putea să predea în propria sa casă sau în anumite încăperi potrivite acestui scop, chiar într-un templu59. Înființarea celor două școli permitea tinerilor romani să fie prezenți la „cursuri” ca ascultători (auditores) și să observe modul în care jurisconsulții îşi conduceau munca juridică6o .

\footnotetext{
55 Ulpian, D. 50.13.1.5.

${ }^{6}$ Anton Hermann Chroust, op.cit., p. 604.

57 Idem, p. 601.

${ }^{58}$ Aulus Gellius, op.cit.

59 Anton Hermann Chroust, op.cit., p. 601-602.

${ }^{60}$ Charles Phineas Sherman, op.cit., p. 501.
} 
În ceea ce privește diferențele conceptuale, în linii mari, ele au fost acelea că sabinienii înclinau spre a oferi continuitate regulilor tradiționale ale formalismului roman, în timp ce proculienii preferau să vadă Dreptul Roman între o lumină progresivă. Interesant de punctat este că atât Capito, cât și Labeo, fondatorii oficiali ai celor două scholae, au emis păreri juridice bazându-se pe forma tradițională a Dreptului Roman, cea din timpul Republicii, doar ulterior părerile lor luând căi distincte în ceea ce privește soluționarea spețelor. Deosebirile de opinie dintre ele au durat până în timpul lui Hadrian ${ }^{61}$ când, datorită reputației și influenței ilustrului Iulian, conducătorul școlii sabiniene de atunci, „totul a devenit sabinian, iar proculianii au dispărut"62.

Pomponius remarcă o asemănare interesantă referitoare la transmiterea calităţii de profesor de la un jurisconsult la altul: se utiliza termenul succedit ${ }^{63}$ pentru a-i enumera pe conducătorii școlilor sabiniană și proculiană, fapt ce nu era întâlnit și în înșiruirea juriștilor republicani.

Dacă la finele Republicii, profesorii de Drept se foloseau doar de instrucţiuni practice pentru a preda, în timpul Imperiului acestea au fost înlocuite cu sistematizarea noțiunilor în cadrul aşa-numitor manuale Institutiones. Cea mai cunoscută dintre ele este Instituțiile lui Gaius, în domeniul dreptului privat și care a supraviețuit aproape intactă până în zilele noastre. Tot aici amintim o lucrare a lui Florentinus, cu același titlu, ce exista la începutul Imperiului. Alături de aceste lucrări cu caracter educațional, Dreptul Roman a mai cunoscut: Septem libri de iure civili a lui Iunius

${ }^{61}$ Edwin Charles Clark, op.cit., p. 128.

62 Edwin Charles Clark, op.cit., p.107-129. Karlowa, Rom. Rechtsgeschichte, I, p. 709 apud Charles Phineas Sherman, op.cit., p. 502.

63 Pomponius, D. 1.2.2.51. 
Brutus $^{64}$ și lucrarea lui Masurius Sabinus, în prima jumătate a primului secol; lucrarea lui Pomponius, care tratează istoria instituțiilor juridice și a personalităţilor din domeniu, la mijlocul sec. II d. Hr.; o varietate de colecţii despre reguli și definiții juridice, cea mai veche datând în jurul anului 100. Mai mult, există mențiuni despre jurisconsulți care au redactat manuale numite Instituții și în sec. III d.Hr. ${ }^{65}$.

Spre deosebire de faza incipientă a Imperiului, la sfârşitul celui de al doilea secol al erei creștine, la Roma existau mai multe locuri stabilite unde se putea studia Dreptul ${ }^{66}$. Ulterior, acest tip de școli s-a răspândit în întregul areal roman: la începutul sec. III, o școală de Drept a fost creată la Berytus (modernul Beirut) în Siria, în care Ulpian a fost profesor ${ }^{67}$. Acea școală a rivalizat cu cele din Roma și din Constantinopol, înființată în sec. IV. Sub multe aspecte, unul dintre cele mai importante orașe-stat feniciene ${ }^{68}$ din timpul Imperiului Roman a fost Berytus, iar în ceea ce privește învățământul superior, acest oraș a devenit gazda uneia dintre cele mai faimoase școli de Drept Roman. Fondată probabil de către Septimius Sever69, spre mijlocul celui de al treilea secol după Hristos şi având ca profesori renumiți pe

\footnotetext{
64 Cicero, De Oratore, 2.32.142, 2.55.224.

65 Andrew Riggsby, op.cit., p. 447. Printre jurisconsulții care şi-au dedicat timpul şi muncii academice îi enumerăm pe Papirius Justus, Callistratus, Paulus, Marcian, Florentinus, Gaius, Paulus, Ulpian.

${ }^{66}$ Aulus Gellius, Nopți Atice, 13.10.13.

67 Henry John Roby, Introduction to the Study of Justinian's Digest, Cambridge University Press, Cambridge, 2011, p. 107-110.

68 Fenicia este recunoscută ca fiind leagănul originii alfabetului, din care grecii, iar apoi romanii s-au inspirat. Această moștenire filologică poate fi explicaţia pentru care romanii au acceptat, apoi au promovat orașul Berytus ca loc pentru una dintre cele mai vechi școli de Drept.

http://www.duhaime.org/LawMuseum/LawArticle-1538/250-The-First-Law-School.aspx accesat la data de 21.07.2020.

69 Fay-Cooper Cole, Harris Gaylord Warren, An illustrated History of Mankind, vol.1, ed. Grolier, New York, 1965, p. 41. Această școală de Drept apare în documentele istorice încă înainte de 250 d.Hr., profesorii de aici fiind numiți iuris professio.
} 
Papinian și pe studentul acestuia, Ulpian, ambii nativi în Fenicia, datorită succesului așezământul a primit denumiri ca Beritus Nutris Legum (Beirut, mamă a Dreptului), oraşul dreptului (Nonnus) şi moaşa oricărui drept (Iustinian) ${ }^{70}$. Această școală și-a arătat eficiența în ultima etapă de dezvoltare a filozofiei și dreptului în Imperiu, datorită faptului că în acea perioadă societatea romană a fost puternic influențată de cultura răsăriteană ${ }^{71}$. De asemenea, mijlocul sec. VI d.Hr. l-a furnizat ca profesor și pe Dorotheus, unul dintre cei mai importanți juriști din timpul lui Iustinian. Totodată, această instituție este cunoscută că a format avocați și magistați pentru următoarele trei secole ${ }^{72}$. Educația juridică în facultate a durat, inițial, patru ani și presupunea studierea Dreptul Roman sub toate aspectele lui; apoi perioada de studiu a crescut la cinci ani, fiind consacrată printr-un decret al împăratului Anastasius (491-518), în anul 50573. Din păcate, Berytus a fost complet distrus în timpul unui cutremur în anul 551. Ulterior, școala din acest oraș a fost transferată la Sidon, însă schimbarea locului nu a adus cu sine și un sol fertil pentru continuitatea vitalității și a prestigiului acestei forme de învățământ74. Avocații care pledau în instanță aveau studii la Berytus, la Roma, ori la Constantinopol și, deoarece această profesie era foarte onorată în Imperiul Roman, numărul studenților creștea perpetuu. Auzind despre avantajele profesionale oferite celor care studiau Dreptul, mulți tineri greci s-

\footnotetext{
${ }^{70}$ Anton Hermann Chroust, op.cit., p. 607.

${ }^{71}$ Averil Cameron, The Cambridge Ancient History Empire and Successors, A.D. 425-60o, Cambridge University Press, Cambridge, 2000, p. 254 apud Ahmet Karakocali, op.cit., p. 44. 72 George Rawlinson, History of Phoenicia, ed. Longmen, Green \& Co., 1889 apud http://www.duhaime.org/LawMuseum/LawArticle-1538/250-The-First-Law-School.aspx. 73 Cod. 2.7.22.4, 2.7.24.4. Anton Hermann Chroust, op.cit., p. 608. 74 https://phoenicia.org/law.html accesat la data de 21.07.2020.
} 
au înscris la școala din Beirut, în ciuda obstacolului pe care îl reprezente limba latină, barbară în opinia lor75.

Chiar dacă s-a semnalat o oarecare ingerință a principelui, la începuturile Imperiului studiul Dreptului nu era o chestiune sprijinită în totalitate de conducerea romană. Odată cu venirea la domnie a lui Dioclețian (284-305), autoritățile imperiale s-au concentrat pe recunoașterea oficială a școlilor din Roma și Beirut, apoi a celor din Constantinopol, Alexandria și Cezareea $^{76}$, desființându școlile private de Drept 77 .

Pe acest fond, începând cu anul 425 au apărut profesori de Drept angajați în toate facultățile amintite mai sus. Deși numărul lor era unul mic, acești profesori erau înconjurați de un număr mai mare de subalterni, iar despre cei din urmă avem cunoștință că au fost opriți prin decret imperial de a preda în public ${ }^{78}$. De exemplu, dacă în anul înființării școlii de Drept de la Constantinopol (425) ${ }^{79}$ se făcea referire numai la doi profesori de Drept, în 533 împăratul Iustinian amintește un număr de opt de astfel de cadre didactice: probabil patru în Beirut și patru în Constantinopol. Deși se cunoaște foarte puțin despre îndatoririle administrative pe care le dețineau profesorii în timpul Dominatului, avem dovada că în anul 425 împărații Theodosie al II-lea și Valentinian al III-lea au decretat că Leontius, un profesor de Drept de la școala din Constantinopol, să primească anumite titluri și ranguri imperiale ${ }^{80}$. Mai mult, cadrele didactice erau scutite de orice tip de taxă şi nu li se impuneau niciunul dintre acele servicii publice

\footnotetext{
75 https://www.britannica.com/topic/education accesat la data de 21.08.2020.

${ }^{76}$ James Muirhead, Historical Introduction to the Private Law of Rome, ed. a II-a, Lawbook Exchange, 2009, p. 400.

77 Ahmet Karakocali, op.cit., p. 45 .

78 C. Th 14.9.3pr. Andrew Riggsby, op.cit., p. 449.

79 C. Th. 14.9, Cod. 11.8 .

${ }^{80}$ Anton Hermann Chroust, op.cit., p. 613.
} 
împovorătoare din timpul Imperiului ${ }^{81}$. Din păcate, primele veacuri ale Dominatului nu au pus în lumină profesori de Drept prestigioși, aşadar scrierile acestora - cu excepția meritelor lor academice - au avut o foarte mică influență din punct de vedere practic asupra dezvoltării științei dreptului ${ }^{82}$. Acest lucru însă nu se întâmplă și în timpul celui de-al V-lea secol, deoarece la Beirut și la Constantinopol și-au făcut apariția multe minți luminate. Astfel, putem enumera pe Erotius (care a fost parte în comisia Codului Theodosian), Cyrillus, Domnius, Demosthenes, Eudoxius, Patricius și Leontius, care sunt remarcați de nenumărate generații de avocați și jurisconsulți ca profesori faimoşi. În timpul primei jumătăți a secolului șase, cei mai renumiţi profesori de Drept de la Constantinopol au fost Theophilus, Thalelaeus, Dorotheus și Anatolius. Din nefericire, numele profesorilor de Drept care au predat în aceeași perioadă la Roma sunt necunoscute, cu excepția lui Floridus, care ar fi activat acolo ${ }^{83}$.

În ceea ce priveşte latura pedagogică aplicată în şcoli, aceasta a înflorit sub toate aspectele ei academice. Studenții erau acum subiecți ai unui program intensiv de studiu, aveau o curriculă obligatorie, foarte bine organizată și care, la terminarea facultății, susțineau un examen final ${ }^{84}$. Sub aspectul numărului învăţăceilor care frecventau universităţile romane, nici acesta nu a scăpat de sub controlul autorităților, deoarece s-a impus și aici o numerus clausus ${ }^{85}$. Totodată, taxele achitate pentru participarea la cursuri au fost stabilite de $\mathrm{Stat}^{86}$ şi, deoarece a fi profesor de drept reprezenta o opera

\footnotetext{
${ }^{81}$ Cod. 10.53.6.

82 Anton Hermann Chroust, op.cit., p. 605.

83 Idem, p. 613-614.

84 Idem, p. 607.

85 Cod. 2.7.11, 17.

86 Clyde Pharr, op.cit., p. 265.
} 
liberalis, maestrul nu se putea întrepta în instanță împotriva studentului care nu și-a achitat contravaloare studiilor ${ }^{87}$. Despre studenții din Constantinopol şi, probabil, din Beirut și Roma știm că erau exceptaţi de la orice obligație publică până la vârsta de 25 de ani, când se considera că și-au finalizat studiile. Simultan, împărații au fost preocupați ca și elevii străini care frecventau cursurile școlilor imperiale să aibă o ținută decentă, să se îmbrace precum un roman, cu togă și sandale ${ }^{88}$, iar tunsoarea să fie una adecvată, nacceptânduse purtarea părului lung89. Mai mult, odată cu declararea creștinismului ca religie de stat, cel care dorea să profesese în domeniul juridic trebuia să demonstreze și faptul că era membru activ al respectivului cult ${ }^{90}$. Cu referire la femei, acestea nu erau acceptate ca studente ale universităţilor imperiale ${ }^{91}$. Pe fondul tulburărilor politico-administrative, școlile de Drept din Cezareea și din Alexandria au fost închise de către Iustinian în anul 533 ${ }^{92}$, sub pretextul că acestea ar preda doctrina adulterina ${ }^{93}$. În cealaltă parte a Imperiului, școala de Drept din Roma a supraviețuit invaziei ostrogoților, așa cum reiese din Ordonanță regală a lui Alaric: în acest act se face mențiune despre existența profesorului de Drept, printre alți profesori (nec non et juris expositor) ${ }^{94}$. Când Iustinian a recucerit Italia în anul 554, el a continuat să finanțeze Universitatea de la Roma asemeni regilor ostrogoții ${ }^{95}$, iar metodele

\footnotetext{
87 Ulpian, D. 1.13.1.3.

88 C. Th. 14.10.2.

89 C. Th. 14.10.4.

90 Cod. 1.4.15-17.

${ }^{91}$ Ulpian, D. 1.15.

92 Const. Omnem 7.

93 Anton Hermann Chroust, op.cit., p. 608.

94 Sheldon Amos, The History and Principles of the Civil Law of Rome: An Aid to the Study of Scientific and Comparative Jurisprudence, Kegan Paul, Trench \& Co., London, 1883, p. 103 apud Charles Phineas Sherman, op.cit., p. 504.

95 Charles Phineas Sherman, op.cit.
} 
de predare care urmau a fi aplicate erau similare celor implementate cu 20 de ani în urmă, în Estul Imperiului. Tot în sec. VI d.Hr. mai sunt menționate ca centre universitare Atena, Antiohia și Augustodorum. Ultimul oraş prezintă un interes particular deoarece acesta este cunoscut ca fiind un centru educațional prestigios, însă o școală de Drept este evidențiată numai într-un manuscris în comentariul la Gaius, descoperit în anul 1800. Ne putem imagina că asemenea şcolii din Augustodorum ar fi putut exista și altele, mai mici, despre care însă nu avem nicio dovadă istorică ${ }^{96}$.

Înainte de a discuta despre scopul și detaliile programelor de studiu anterior și după Iustinian, este interesant să amintim faptul că studenții purtau anumite apelative academice sau porecle, în funcție de anul în care învățau ${ }^{97}$. Cei din anul întâi erau numiți - până la Iustinian -dupondii, iar în timpul domniei acestuia - Iustiniani novi; cei din anul doi purtau porecla de edictales $^{98}$, în timp ce anul trei de studiu îi avea ca actori principali pe papinianiste, nume împrumutat de la regele jurisconsultțiilor romani, Papinian. În ceea ce privește anii patru și cinci aceștia erau denumiți lytae (gr., cei care rezolvă probleme juridice) ${ }^{99}$, respectiv prolytae (lytae avansați). Astfel, perioada de studiu în cadrul Facultății de Drept se concentra în trei ani petrecuți sub îndrumarea unui profesor și alți doi, în care studiul dobândea un caracter privat.

Despre prima parte a Imperiului știm foarte puțin în ceea ce privește curricula și metodele de predare. Din păcate, în acest sens, cele mai sigure dovezi datează din sec. VI d. Hr., perioadă în care se realizează cea mai intensă

\footnotetext{
96 Andrew Riggsby, op.cit., p. 450.

97 Const. Omnem 2, 4, 5.

98 Purtau această denumire deoarece studiau Edictul perpetuu apărut în timpul lui Salvius Iulianus.

99 https://openjurist.org/law-dictionary/lytae, accesat la data de 09.09.2020.
} 
dezvoltare a învățământului juridic, după cum vom detalia mai jos. Revenind la sec. III d. Hr., un tânăr care aspira la profesia de avocat nu mai urma cursurile unei școli de retorică, asemeni perioadei republicane, deoarece toate cunoștințele necesare erau oferite de școlile de Drept. Astfel, el va intra întrun program sistematic și riguros de învățare, sub tutela unor profesori specializați în domeniu ${ }^{100}$. Studierea cu seriozitate a chestiunilor juridice era un pas sigur către cele mai influente poziții din conducerea Imperiului, fapt ce a determinat mulți tineri să urmeze cursurile școlilor de Drept. Așadar, cu trei secole înainte de Iustinian, neofiții în Drept îşi începeau studiul cu operele lui Gaius: învățau astfel despre proprietate, curatelă, testamente și succesiuni. De asemenea, este pomenită o lucrare anonimă, Libri Singulares, care ar fi avut rolul de manual pentru primul an de studiu, mai ales la Beirut ${ }^{101}$. În anii doi şi trei ai cursurilor, studenții luau cunoștință cu Edictul pretorului şi cu Comentariile lui Ulpian, urmate de studiul a 8 din cele 19 cărți din Răspunsurile lui Papinian. Viitorii juriști din anul patru se îndeletniceau cu Răspunsurile lui Paul, iar cei din anul cinci studiau constituțiile imperiale ${ }^{102}$. Avem, totodată, mărturii despre existența unor exerciții numite controversia care presupuneau ca studenții să se poziționeze de partea pârâtului, respectiv a reclamantului și pledau în favoarea celui pe care îl apărau, în contextul unui proces fictivio3.

Așa cum observăm, până la Iustinian, materia predată de-a lungul perioadei de studiu este una foarte clară, în schimb, metodele pedagogice pe care le-au utilizat profesorii de Drept Roman nu sunt la fel de cunoscute astăzi. Ceea ce știm cu siguranță este că în anul patru studenții recitau pe de

\footnotetext{
100 Anton Hermann Chroust, op.cit., p. 572.

${ }^{101}$ Idem, p. 608.

102 Henry John Roby, op.cit., p. 27.

103 Andrew Riggsby, op.cit., p. 448.
} 
rost din Paul104, în această etapă profesorii se retrăgându-se din predarea activă și făcând loc la ceea ce am numit mai sus personal auxiliar care ajuta studenții în aprofundarea cunoștințelor. Anul 460 este decisiv pentru cei care doreau să profeseze în domeniul juridic deoarece împăratul Leo I (457-474) va institui ca obligatorie urmarea cursurilor unei facultăți, anterior accederii în avocatură şi, mai mult, candidatul trebuie să dea un examen final în fața unei comisii specializate ${ }^{105}$. Alăturat, s-a decis ca pe lângă cunoștințele în Drept aspirantul la avocatură trebuie examinat și din punct de vedere al caracterului, al status-ului și al experienței sale în serviciile publice ${ }^{106}$. Absolventului i se cerea, de asemenea, să jure în fața profesorilor că va respecta cu strictețe regulile juridice și legile imperiale. Important de menționat este că această regulă se aplica numai în partea de Răsărit a Imperiului, Vestul preferând ca practicienii în Drept să provină din vechi oratori care, de multe ori, aveau nevoie de ajutorul jurisconsulților în ceea ce privește instrucțiunile în domeniul juridic. În acest sens, un tânăr care își dorea să devină avocat putea urma cursurile școlii de Drept de la Roma, însă nefiind necesare, cei mai mulți preferau să studieze într-o școală de retorică. Alegerea respectivă a fost încurajată și de către Valentinian al III-lea, care în anul 442 a impus cerința unor studii sistematizate anterior accederii în profesia de avocat, însă pregătirea cerută de către împărat nu se referea la știința dreptului ${ }^{107}$.

Aceasta fiind situația până în sec. VI d. Hr., reformele lui Iustinian au constat în faptul că învățăceii științei Dreptului trebuiau să studieze numai

\footnotetext{
104 Const. Omnem 1.

105 Cod. 2.7.11.2, 2.7.22.4, 2.7.24.2.

106 Anton Hermann Chroust,op.cit., p. 574-575.

107 Idem., p. 573-574.
} 
din cărțile impuse de el, deoarece cele apărute anterior deveniseră desuete ${ }^{108}$. Mai mult, ordinea studierii materiilor era una prestabilită. Prin modificările din justiție ale lui Iustinian, candidații la o profesie juridică studiau întregul Corpus Iuris (după denumirea cunoscută astăzi), astfel: Instituțiile, Digestele şi Codul. Prin urmare, în primii trei ani studenţii erau iniţiaţi în Instituţii și în primele cinci părți din Digeste, iar următorii doi îi petreceau învățând restul Pandectelor și Codex-ul ${ }^{109}$. Așadar, predarea acestei ştiințe nu se mai realiza după dorința unui anumit profesor, iar candidații care doreau să ocupe un loc în tagma avocaților erau obligați, în continuare, să promoveze un examen public înainte de a li se acorda privilegiul de practician al Dreptului ${ }^{110}$.

Prin urmare, încă din primul an se începea cu citirea Instituțiilor, carte formată din patru părți, ceea ce oferea începătorului o privire de ansamblu asupra întregii științe a Dreptului. Pasul următor era acela de a studia Digestele, anume primele patru cărți care conțin chestiuni generale și introductive în materie: concepte fundamentale și definiții, originea Dreptului din punct de vedere istoric, tipuri și diviziuni ale acestuia, părțile esențiale din dreptul persoanelor, bunurile care cad asupra proprietății private, drepturile și îndatoririle magistraților și ale reprezentanților oficiali ai Statului. Apoi, studentul urma să parcurgă chestiunile de procedură, analiză care nu se încheia decât la mijlocul anului doi de studiu (cărțile 2 și 3). Menționăm faptul că a patra carte, care completează cunoștințele acumulate în primul an, tratează numai noțiuni de procedurăă ${ }^{111}$. Ca o concluzie, sub domnia lui Iustinian, studenții își petreceau primul an făcându-și o viziune de

\footnotetext{
108 Const. Omnem. 1.

109 Const. Omnem 5.

110 Thomas Mackenzie, Studies in Roman Law: With Comparative Views of the Laws of France, England, and Scotland, University of Michigan Library, 1865, p. 387.

${ }^{111}$ Henry John Roby, op.cit., p. 34.
} 
ansamblu asupra întregului domeniu al Dreptului: concepte fundamentale şi principii, aranjate într-un sistem logic și lucid, uşor inteligibil pentru novicii în ale științei juridice ${ }^{112}$.

$\mathrm{Al}$ doilea an de studiu începea cu cărțile 5-11 din Digeste pentru ca, aşa cum era obiceiul, cărțile 12-19 să fie păstrate pentru anul al treilea, tocmai cu scopul de a permite studenților să definitiveze materia procedurii de judecată începută în anul întâi. În ansamblu, se punea accentul asupra acțiunilor in rem însă, complementar acestora, studentul anului doi își îndrepta atenția și asupra cărții 26 din Digeste - care tratează subiectul curatelei și al tutelei, apoi asupra cărții 28 - în care regăsim informații despre testamente și a cărții 30 care tratează domeniul succesiunilor. Parcurgerea acestor din urmă trei cărți avea scopul de a-i pregăti pe învăţăcei pentru materia anului trei.

În continuare, papinianiste începeau cu a treia parte a Digestelor, cărțile 12-19, studiind drepturile in personam, contractele și noțiuni din domeniul comercial. Alăturat, studenții anului trei parcurgeau cărțile 20-22, învăţând despre despre gaj, despre rezilierea unui contract de vânzare, despre evacuare şi alte elemente caracteristice contractelor. $\mathrm{Cu}$ acestea putem spune că se încheia anul trei de studiu într-o facultate de Drept, în timpul lui Iustinian.

Cei din anul patru trebuiau să parcurgă părțile 23-36 din Digeste, dobândind cunoştințe despre dreptul familiei și despre succesiuni.

Programul de studiu al anului cinci se continua prin învățarea a ceea ce a mai rămas din Pandecte, cărțile 37-50 și a întregului Codex ${ }^{113}$, în care cea mai veche constituție inclusă este din timpul împăratului Hadrian, restul aparținând împăraților subsecvenți, inclusiv lui Iustinian (anterioare anului

\footnotetext{
${ }^{112}$ Chief Justice Baldwin, The Study of Elementary Law, in Yale Law Journal nr.13, 1903, p. 2. 113 Const. Omnem 5.
} 
534). Materia tratată în Cod este densă și variată, acoperind domenii din ceea ce numim astăzi drept public, drept bisericesc, drept penal și drept civil. Dacă parcurgem cuprinsul Digestelor și pe cel al Codului, vom observa asemănări în ceea ce privește modul de sistematizare a materiilor în cadrul acestora. Explicația rezidă din faptul că Pandectele au fost modelate după matricea Codex-ului. Abordarea de către Gaius a științei dreptului din punct de vedere instituțional, după care au fost modelate și Instituțiile lui Iustinian, luciditatea exegetică și scrierile analitice ale lui Papinian, răspunsurile critice, dar ușor de înțeles ale lui Ulpian și ale lui Paul, la care adăugăm munca altor juriști, au transformat Digestele într-o combinație științifică de succes care a adunat în cuprinsul ei un număr impresionant de cazuri, reguli, decizii ce au convertit, ulterior, lucrarea respectivă în sursă de Drept ${ }^{114}$.

După cum am observat, metoda folosită de către profesorii din epoca iustiniană în predarea Dreptului a fost una de tip concentric ${ }^{115}$. Disciplina interioară și cultivarea obiceiului de a avea o gândire clară și limpede nu erau deloc neglijate în sistemul legal de educație romană. Ultimii ani pe care studenții îi petreceau în cadrul instituției de învăţământ nu ar fi dus la o mai rapidă modelare a facultăţii analitice şi abilități inductive de gândire a studenților, dacă aceștia nu ar fi fost obligați să studieze anumite cazuri ilustrate în Digeste. În concluzie, putem spune că studentul era învăţat cum să aplice principiile legale la stările de fapt, iar Dreptul Roman era predat ca un sistem al unei științe deductive, Corpus Iuris începând prin enunțarea principiilor și continuând cu aplicarea acestora la nenumărate cazuri practice $^{116}$.

\footnotetext{
114 Charles Phineas Sherman, op.cit., p. 511.

115 John Wurts, Systems in Legal Education, în Yale Law Journal nr.17, 1907, p. 95. ${ }^{116}$ Chief Justice Baldwin, op.cit., p.12.
} 
O chestiune inedită în ceea ce privește școlile de Drept o reprezintă modalitatea de disciplinare a studenților. Personajul care deținea această atribuție era numit censuales și avea îndatorirea de a-i pedepsi fizic, de a-i biciui și chiar de a-i exclude din școală pe cei care nu-și ascultau profesorii sau erau tulburenți. În Constantinopol, cel puțin din vremea împăratului Iustinian, studenții se aflau sub supravegherea unui praefectus urbi, în timp ce în Beirut chestiunile disciplinare aparţineau ori guvernatorului din Fenicia, ori decanului Facultății de Drept. De asemenea, împăratul Iustinian a interzis hărțuirea profesorilor de către studenți și a pedepsit orice formă de nesupunere a celor mai tineri ${ }^{117}$.

Referitor la limba în care se studia Dreptul în Roma Antică, aspectele sunt diferite, în funcție de epoca la care ne raportăm. În faza de final a Republicii, maeștri jurisconsulți utilizau doar latina, însă în Imperiu, chiar dacă textele și materialele folosite în manuale erau scrise în aceeaşi limbă, cursurile publice, cel puțin la Beirut și la Constantinopol, erau susținute în limba greacă ${ }^{118}$.

Înainte de a încheia expunerea noastră, amintim faptul că la Roma, cel puțin în Imperiu, existau specialiști în Drept care își desfăşurau activitatea singuri sau erau coordonați de către alți jurisconsulți, cu studii în domeniu ${ }^{119}$. Această categorie de experți reprezenta marea majoritate a celor care lucrau în sistemul juridic, însă nu avem nicio informație despre felul în care își formaseră educația. Au fost autodidacți, textele legale fiind disponibile publicului larg? Au studiat în școli de Drept mai puțin importante și deloc cunoscute nouă, din lipsa dovezilor istorice? De exemplu, în Satyriconul lui

\footnotetext{
117 Anton Hermann Chroust, op.cit., p. 610.

118 Idem, p. 611.

119 Pentru detalii a se vedea Pop Cristina, op.cit.
} 
Petroniu, un personaj se laudă că a cumpărat câteva cărți de Drept pentru a-l instrui pe fiul său, chiar dacă scopul lui era ca odrasla să devină om de afaceri sau avocat, nu un adevărat jurisconsult. Așadar, putem doar să presupunem că variantele de mai sus erau utilizate de către tabelliones, însă cum și în ce proporție, nu putem preciza ${ }^{120}$.

În ansamblu, recunoaștem că profesiile juridice și corpul bărbaților care au predat Dreptul, mai mult decât reprezentanții oficiali ai putrii centrale, au constituit cel mai dominant factor dintre cei care au făurit acest domeniu și au contribuit la dezvoltarea lui. Ei sunt primii creatori, promotori şi administratori ai Dreptului, după desprinderea acestuia de fas. În concluzie, putem vorbi despre o știință a dreptului vie, legată de amploarea pe care au luat-o profesiile juridice competente și care au permis persoanelor instruite în acest sens să pledeze în instanță. Totodată apreciem atitudinea matură a romanilor față de evoluția sistemulului juridic: onorând această categorie de profesioniști, cetățenii Imperiului Roman au oferit lumii un sistem de drept evoluat, chiar dacă Imperiul s-a destrămat ${ }^{121}$.

Acestea fiind precizate, este de la sine înțeles faptul că programul folosit pentru educația juridică în granițele romane a atins o măsură înaltă, care a pus în valoare juriști de neîntrecut în abilitatea lor creativă, la nivelul întregii istorii a lumii ${ }^{122}$. Încă de la începuturile Romei, cei care aveau cunoștințele despre aplicarea normelor cu caracter juridic dețineau în cadrul comunității o anumită reputație și, proveniți din familii bogate, aceste persoane puteau accede în poziții înalte ale organelor de conducere sau puteau influența emiterea anumitor legi, practică preluată și în Imperiu. În

\footnotetext{
120 Andrew Riggsby, op.cit., p. 450-451.

${ }^{121}$ Anton Hermann Chroust, Legal Profession in Ancient Republican Rome, în Notre Dame Law Review, vol. 30, 1954, p. 99.

122 Charles Phineas Sherman, op.cit., p. 512.
} 
acest mod, romanii au constatat faptul că, pentru a deține o bază solidă în aspectele legale ale Imperiului, este necesar ca educației juridice să i se acorde o importanță mult mai mare decât în Republică. Din fericire, Dreptul Roman nu ne oferă un spectacol de culise în cadrul dezvoltării societății, deoarece ştiinţa Dreptului a progresat și s-a modificat continuu, ținând pasul cu schimbările și dezvoltările fiecărei perioade istorice în parte. Acelaşi lucru îl putem spune și despre educația juridică, ea apărând ca diferită în momentele istorice distincte ale Romei Antice ${ }^{123}$ : o oarecare predare sistematizată și elementară a Dreptului s-a ivit la Roma încă din ultimele zile ale Republicii, extinzându-se apoi în majoritatea orașelor din Peninsula Italică, iar, în final, şi-a făcut apariţia şi în provincii, în secolele II și III ${ }^{124}$.

Educaţia juridică romană este egală, dacă o cântărim după meticulozitate, după exhaustivitate, după disciplina gândirii și cultivarea puterii de a gândi cu ceea ce se întâmplă astăzi în marile universități, meritându-și locul printre cele mai bune sisteme de educație juridică din lume. În concluzie, Roma a învățat omenirea că o civilizație complexă și dezvoltată nu își găsește stabilitatea și eficiența fără un sistem juridic matur care, la rândul lui, necesită prezența și activitatea unui corp competent, loial și respectat de profesioniști formați în școlile de specialitate, de importanță vitală fiind faptul că educația juridică romană și, înaintea ei, Dreptul - ca știință - au fost acceptate ca părți ale vieții și ca importante moduri de a gândi.

\footnotetext{
123 Ahmet Karakocali, op.cit., p. 45.

${ }^{124}$ Anton Hermann Chroust, Legal Profession in Ancient Imperial Rome, în Notre Dame Law Review, vol. 30, 1955, p. 600.
} 